\title{
Pengaruh Model Kulit Bumi terhadap Gelombang ScS dan ScS-ScS
}

\author{
Bagus Jaya Santosa* \\ Juruan Fisika, FMIPA, Institut Teknologi Sepuluh Nopember \\ Kampus ITS Sukolilo, Surabaya 60111
}

\begin{abstract}
Intisari
Dalam penelitian ini telah diperbandingkan seismogram observasi dengan seismogram sintetik dari sebuah gempa dalam komponen ruang 3 dimensi. Data seismogram berasal dari Teluk Kamschatka di Kep. Kuril yang terjadi pada tanggal 5 Desember 1997, dan direkam oleh stasiun pengamat yang terletak di BILL, Rusia dan MAJO, Jepang. Seismogram sintetik dihitung dengan Program GEMINI, yang mana inputnya berupa sebuah model bumi elastik, yang simetri radial dan isotrop tranversal, dan solusi CMT dari gempa tersebut, yang merupakan penggambaran atas proses dinamika pada hiposenter gempa serta kedudukan-kedudukan stasiun observasi. Model bumi diambil dari dua model yang paling sering diacu oleh para peneliti, yaitu IASPEI91 dan PREM. Data seismogram riil dan sintetik akan diperbandingkan dalam kawasan waktu pada ketiga komponen pergerakan tanah, setelah sebelumnya dikenakan filter lolos rendah pada $20 \mathrm{mHz}$. Pada perbandingan seismogram dijumpai diskrepansi yang jelas pada amplitudo dan waktu tiba milik fase gelombang ScS dan $\mathrm{ScS}-\mathrm{ScS}$. Ini menunjukkan, bahwa struktur inti bumi dan lapisan mantel bawah belum diketahui secara detil, karena pengaruh dari ketebalan kulit bumi yang sangat jelas.
\end{abstract}

KATA KUNCI： seismogram, kulit bumi, CMB, mantel bawah

\section{PENDAHULUAN}

\section{A. Latar Belakang}

Sebuah gempa yang besar menghasilkan gerakan tanah yang dapat dicatat di hampir seluruh permukaan bumi (jika kekuatan gempa di atas 5,6 skala Richter). Melalui seismometer yang sensitif di stasiun penerima, gerakan tanah akibat gempa tersebut direkam dan disajikan sebagai seismogram. Seismogram tersusun atas susunan fase gelombang yang kompleks, berasal dari refleksi/refraksi yang terjadi di dalam bumi, akibat adanya perbedaan parameter elastik pada sistem perlapisan model bumi, sepanjang perjalanan gelombang dari sumber gempa hingga penerima.

Beberapa fase gelombang utama dapat dicatat waktu tiba dan polaritasnya. Melalui pengamatan atas waktu tiba gelombang-gelombang utama pada serangkaian seismometer yang melingkupi daerah sumber gempa, ditentukan kemudian episenter gempa [1]. Selain itu polaritas gelombang pertama juga dicatat, guna menentukan arah sesar gempa. Semuanya dikerjakan pada seismogram dengan perioda pendek [2]. Tinggi amplitudo gelombang permukaan pada komponen vertikal juga digunakan untuk menentukan besarnya energi yang dilepaskan ketika gempa [3].

Sebuah pengandaian model bumi diperlukan untuk menghitung simulasi atas besaran fisis yang terukur, yaitu waktu tempuh gelombang, polaritas gelombang dan tinggi amplitudonya.

*E-MAIL: bjs@physics.its.ac.id
Data seismogram juga dapat digunakan untuk menurunkan sebuah model bumi. Ada 3 metode yang digunakan untuk menurunkan model bumi, yaitu analisis onset time fasefase gelombang ruang, analisis dispersi pada gelombang permukaan dan perbandingan seismogram dalam kawasan waktu. Dua metoda disebut pertama hanya mengevaluasi sedikit informasi tertentu dari sebuah deret waktu dalam seismogram. Sedangkan metoda ketiga adalah yang terbaik, karena akan diperbandingkan keseluruhan informasi yang terkandung dalam seismogram $[1,4]$.

Seismogram sintetik dalam domain waktu dan ketiga komponen Kartesian secara simultan dihitung dengan program GEMINI [5, 6], dimana inputnya adalah model bumi elastik secara lengkap, keterangan CMT dari gempa C120597C dan kedudukan-kedudukan stasiun observasi BILL dan MAJO. Guna membandingkan seismogram riil dan sintetik dalam dimensi yang sama, digunakan file response dari stasiun-stasiun observasi tersebut. File response berisi catatan tentang transfer function seismometer di stasiun tersebut.

Model bumi IASPEI91 [7] dan PREM [8] diturunkan dari kompilasi atas jutaan waktu tempuh gelombang dari ribuan pasangan sumber gempa-stasiun pencatat, dengan sedikit informasi tambahan dari analisis dispersi pada gelombang permukaan, untuk melengkapi parameter elastik dari model bumi yang dihasilkan. Model-model bumi ini sering diacu sebagai model awal dalam penelitian kebumian untuk struktur regional ataupun global dengan resolusi yang lebih rinci. Ada banyak sekali penelitian tentang model-model bumi dengan resolusi yang lebih detil $[9,10]$, dimana data yang dievaluasi adalah masih data-data waktu tempuh gelombang dan analisis dispersi pada gelombang permukaan.

Jika sebuah gempa bumi terjadi, Lembaga Seismologi di Negara yang bersangkutan dengan segera mengumumkan 


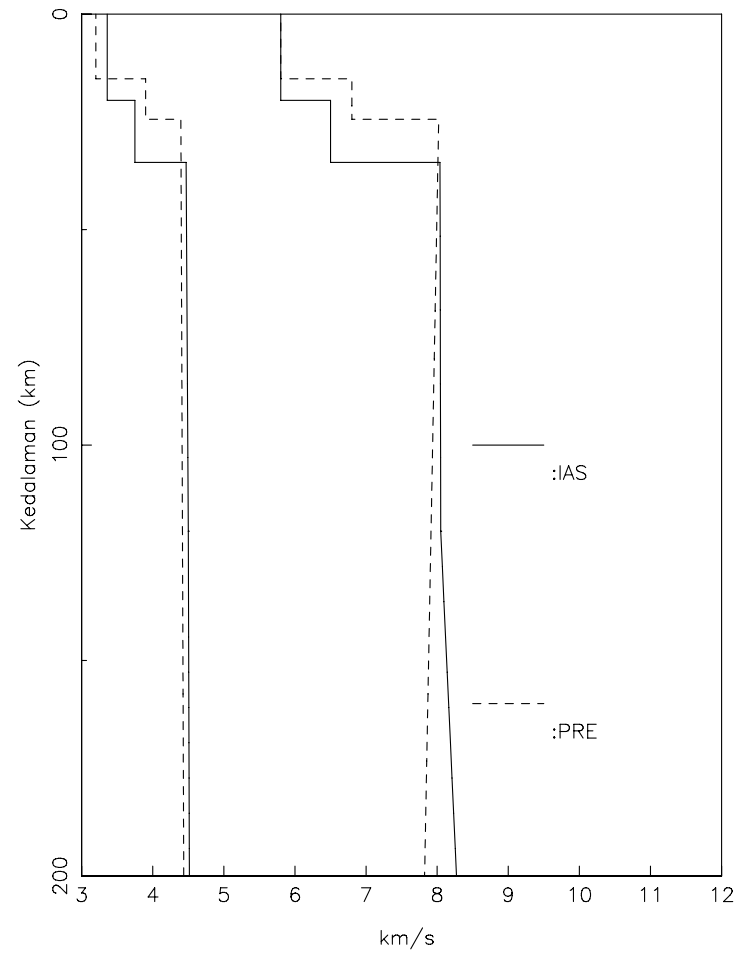

Gambar 1: Penampang model bumi dari kedua model bumi standart, IASPEI91 dan PREMAN hingga kedalaman $200 \mathrm{~km}$.

letak episenter dari gempa tersebut. Beberapa bulan kemu- dian solusi CMT $[3,11]$ yang memuat keterangan mengenai saat awal, lokasi dan mekanisme gempa tersebut diumumkan oleh Lembaga Seismologi Internasional (IRIS, USGS), yang dievaluasi oleh Lab Seimologi Uni. Harvard.

Dalam penelitian ini, seismogram riil dari gempa Teluk Kamschatka, Kep Kuril, 5 Desember 1997, dibandingkan dengan seismogram sintetik, yang dihitung dengan metoda minor-minor fungsi Green $[5,6]$ atas sebuah model bumi elastik dengan solusi CMT dari gempa yang bersangkutan dan posisi geografis kedua stasiun pengamatan. Stasiun pengamat, yaitu pencatat seismogram diambil di daerah sekitar sumber gempa, pada jarak episentral di bawah 25 derajat.

\section{B. Model Bumi}

Dua model bumi yang terkenal, yaitu The Preliminary Reference Earth Model 81 (PREM) [8],selanjutnya disebut PREMAN, dan IASPEI91 [7] dapat dilihat pada Gambar 1.

\section{Solusi CMT}

Solusi CMT menggambarkan mekanisme perpatahan di daerah sumber gempa. Solusi ini dapat diperoleh dari Pusat Data Bank melalui halaman internet, misal dari IRIS [12], dimana tensor solusi telah dihitung oleh Dreger [3]. Keterangan CMT dari gempa yang digunakan dalam publikasi ini adalah sbb :

\section{C120597C 120597112654.754 .84 162.04 33.06.37.6NEAR EAST COAST OF KAMCHATKA}

dimana keterangannya dapat dilihat pada file keterangan allorder.dek (lihat pada [12])

\section{METODOLOGI}

Data seismogram dapat diperoleh dari beberapa Databank Center, yang datanya dapat diakses melalui halaman WWW, diantaranya IRIS [12]. Setiap gempa menghasilkan pergerakan tanah, yang oleh sebuah stasiun akan direkam dalam arah ketiga komponen Kartesian (U-S, T-B dan Z). Setelah data diperoleh kemudian difilter lolos rendah dan diperagakan.

Pertama dalam penelitian ini harus dituliskan program komputer untuk melaksanakan perhitungan atas seismogram sintetik, yaitu program GEMINI [5]. Ketika program ini dijalankan, haruslah sebuah model bumi diberikan sebagai input, yaitu model bumi PREMAN dan IASPEI91. Sebagai model bumi masukan, data harus mengandung parameter elastik secara lengkap, yaitu meliputi kecepatan penjalaran gelombang kompresi dan geser, faktor kualitas redaman dan rapat massa dari batuan penyusun struktur bumi. Disamping data model bumi, untuk mensimulasikan seismogram juga diperlukan keterangan mengenai sumber gempa, yaitu koordinat hiposenter, waktu awal dan arah sesar di pusat gempa dan energi yang dilepaskan gempa, yang kesemuanya dapat ditemukan dalam katalog solusi CMT. Selain itu diperlukan keterangan koordinat geografi dari stasiun pengamat dan file tanggap-respon dari sistem peralatan seismometer di stasiun tersebut, yang telah mengubah kecepatan pergerakan tanah [mm/s] menjadi bilangan digital.

Data pergerakan tanah tiga komponen yang terekam sebagai seismogram sebelumnya diarahkan pada arah utaraselatan, timur-barat dan vertikal. Guna memperjelas perbandingan seismogram yaitu hipotesis atas teori penjalaran gelombang dalam bidang planar dan yang tegak-lurus terhadapnya, bahwa terbentuk gelombang toroidal $(\mathrm{SH})$ dan sferoidal (P-SV), maka komponen-komponen gerakan Kartesian pada bidang horisontal diputar, sehingga sistem koordinat lokal di stasiun pengamat diarahkan pada arah busur kecil ke sumber gempa (arah back-azimuth). Ini untuk mengamati 


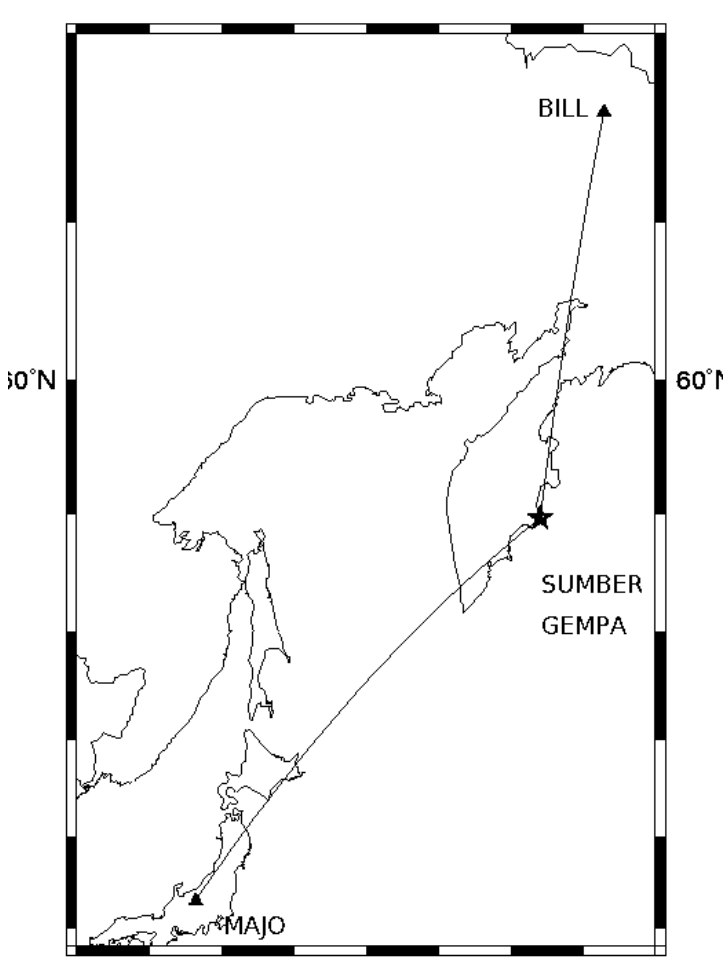

Gambar 2: Penampang model bumi dari kedua model bumi standart, IASPEI91 dan PREMAN hingga kedalaman $200 \mathrm{~km}$.

gelombang SH pada komponen tegak-lurus t, dan P-SV pada komponen searah $\mathrm{r}$ dan tegak vertikal $\mathrm{z}$ terhadap arah busur kecil tersebut.

Letak dari episenter gempa dan kedua stasiun pengamat, BILL dan MAJO diilustrasikan dalam Gambar 2.

\section{ANALISIS DAN PEMBAHASAN}

Dalam penelitian, karena keterbatasan halaman maka ditampilkan analisis sebuah gempa 5 Desember 1997 (54,84 LU, 162,04 BT, Teluk Kamschatka, Kep Kuril), yang gelombangnya ditangkap oleh stasiun observasi seismologi BILL di Rusia dan stasiun observasi seismologi MAJO di Jepang. Data Seismogram, baik observasi ataupun sintetik, keduanya difilter pada frekuensi sudut $20 \mathrm{mHz}$. Pada daerah frekuensi ini tidak ada sumber noise yang dapat membangkitkan gelombang pada daerah frekuensi serendah ini. Pada frekuensi sudut ini, panjang gelombang seismik adalah sekitar $240 \mathrm{~km}$.

Dua stasiun observasi digunakan dalam penelitian ini, dimana jarak episentral sumber gempa stasiun pengamat di bawah 25 derajat. Dengan jarak episentral sedekat ini, fase gelombang ScS dan $\mathrm{ScS}-\mathrm{ScS}$ merambat hampir tegak vertikal ke bawah. Fase gelombang ScS dihasilkan oleh pemantulan gelombang pada batas mantel bawah dengan inti cair (CMB, Core Mantel Boundary), dimana beda parameter elastik kedua batuan cukup besar. Analisis gelombang ScS dan ScS-

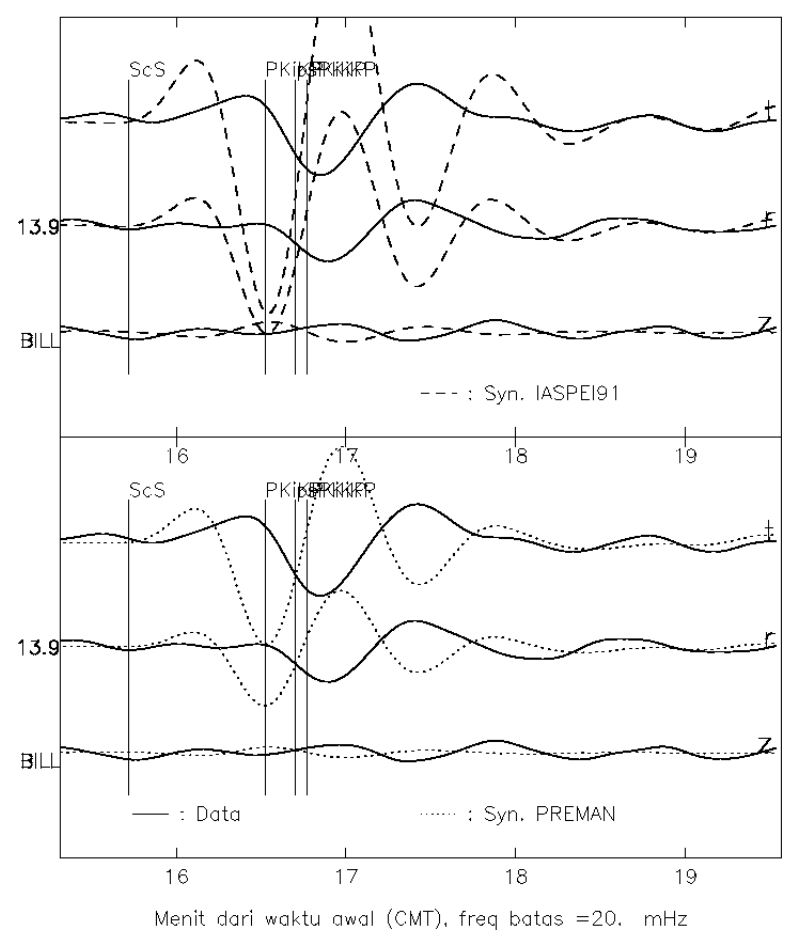

Gambar 3: Perbandingan seismogram dalam kawasan waktu untuk fase gelombang ScS pada stasiun BILL.

ScS pada jarak episentral sedekat ini belum dieksploitasi oleh riset-riset tentang struktur mantle bawah dekat CMB, misal Wysession [13].

Sajian pertama diperlihatkan perbandingan seismogram yang direkam oleh stasiun BILL $\left(68,06^{0}\right.$ LU dan $166,452^{0}$ BT). Gambar 3 memperlihatkan seismogram dalam tiga komponen dan perbandingan seismogram terukur dengan seismogram sintetik yang dihitung dari kedua model bumi, IASPEI91 (tiga trace atas) dan PREMAN (tiga trace bawah). Kita perhatikan pertama tiga trace atas, dimana seismogram sintetik dibangun dari model bumi IASPEI91, terlihat fase gelombang ScS sintetik mempunyai amplitudo yang lebih besar daripada $\mathrm{ScS}$ riil dan juga letak maksimum sintetik terlambat 4 detik di belakang signal riilnya. Pada tiga trace bawah, dimana sintetik dibentuk dari model bumi PREMAN, perbedaan amplitudo antara kedua seismogram mengecil, begitu juga dengan waktu tiba dari maksimumnya. IASPEI91 mempunyai ketebalan kulit bumi sebesar $40 \mathrm{~km}$, sedangkan PREMAN $25 \mathrm{~km}$. Perbedaan $15 \mathrm{~km}$ ini sudah memberikan kontribusi pada perbedaan amplitudo secara nyata walaupun panjang gelombangnya sekitar $240 \mathrm{~km} \mathrm{[14].}$

Pada Gambar 4 dibandingkan dengan cara yang sama, tetapi untuk fase gelombang sekunder repetisi $\mathrm{ScS}-\mathrm{ScS}$, dimana arti dari notasi ini adalah gelombang $\mathrm{ScS}$ yang telah menempuh dua kali penjalaran, dari sumber ke CMB, balik ke permukaan bumi dan terpantul kembali hingga CMB dan terpantul balik ke permukaan (dalam Gambar 4 dan 6 fase gelombang dinotasikan dengan PKKPdf, namun sebenarnya adalah $\mathrm{ScS}-\mathrm{ScS}$, dengan memperhatikan besarnya amplitudo 


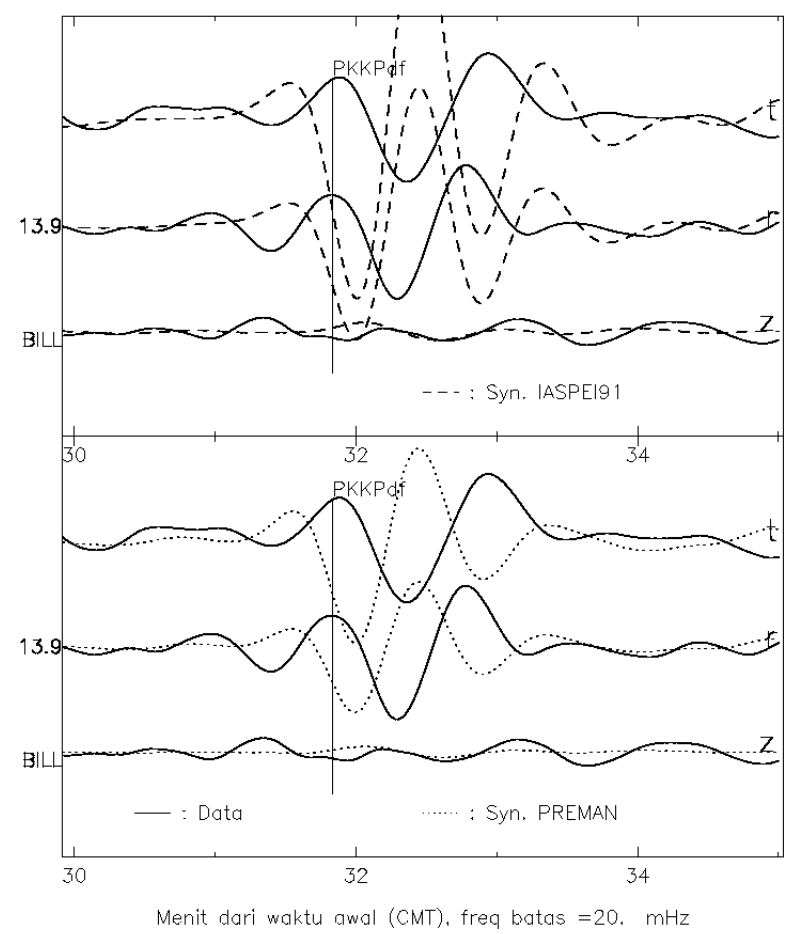

Gambar 4: Perbandingan seismogram dalam kawasan waktu untuk fase gelombang $\mathrm{ScS}-\mathrm{ScS}$ pada stasiun BILL

gelombang di komponen t). Model PREMAN memberikan fitting yang sangat bagus pada amplitudo fase gelombang ScS$\mathrm{ScS}$, walaupun terlihat masih ada keterlambatan sebesar 8 detik. Sementara sintetik yang dibangun dari model bumi IASPEI91 memberikan amplitudo yang tetap lebih besar daripada fase gelombang riil.

Gambar 5 dan 6 menyajikan perbandingan seismogram pada stasiun observasi seismologi MAJO (36, $54^{0} \mathrm{LU}$ dan $138,20^{\circ}$ BT). Dalam Gambar 5 akan diperbandingkan antara gelombang sintetik dengan observasi pada segmen waktu kedatangan gelombang-gelombang ScS. Jika kita perhatikan masing-masing kurva gelombang dengan seksama, maka dapat kita kenali, bahwa model bumi PREMAN (trace tiga komponen bawah) di awal fase ScS komponen toroidal t menunjukkan sebuah pengepasan yang baik pada amplitudonya, namun datang terlambat sebesar 8,2 detik. Sementara seismogram sintetik yang dibuat dari model bumi IASPEI91 (trace atas) meniru seismogram riil dengan sangat buruk, khususnya pada amplitudonya.

Gambar 6 menunjukkan perbandingan seismogram pada jendela waktu fase gelombang ScS-ScS di stasiun MAJO. Seismogram sintetik dari model bumi PREMAN (trace bawah) memberikan fitting pada amplitudo gelombang ini dengan sangat baik, walaupun masih ada keterlambatan sintetik sebesar 4,6 detik. Sementara seismogram sintetik dari model bumi IASPEI91 memberikan amplitudo yang lebih besar daripada signal $\mathrm{ScS}-\mathrm{ScS}$ riil. Analisis seismogram dalam domain waktu pada fase gelombang ScS dan repetisi ScS-ScS pada pada jarak episentral sedekat ini $\left(25^{0}\right)$ memberikan in-
971205 NEAR EAST COAST OF KAMCH(6.3)

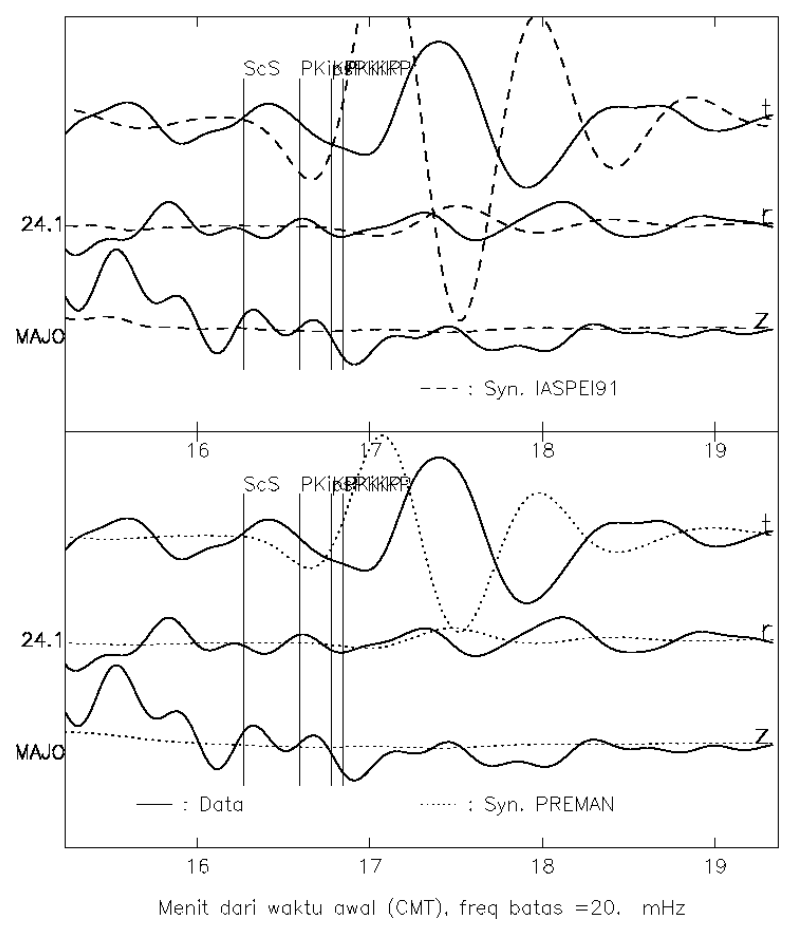

Gambar 5: Perbandingan seismogram pada jendela waktu gelombang $\mathrm{ScS}$ pada stasiun MAJO.

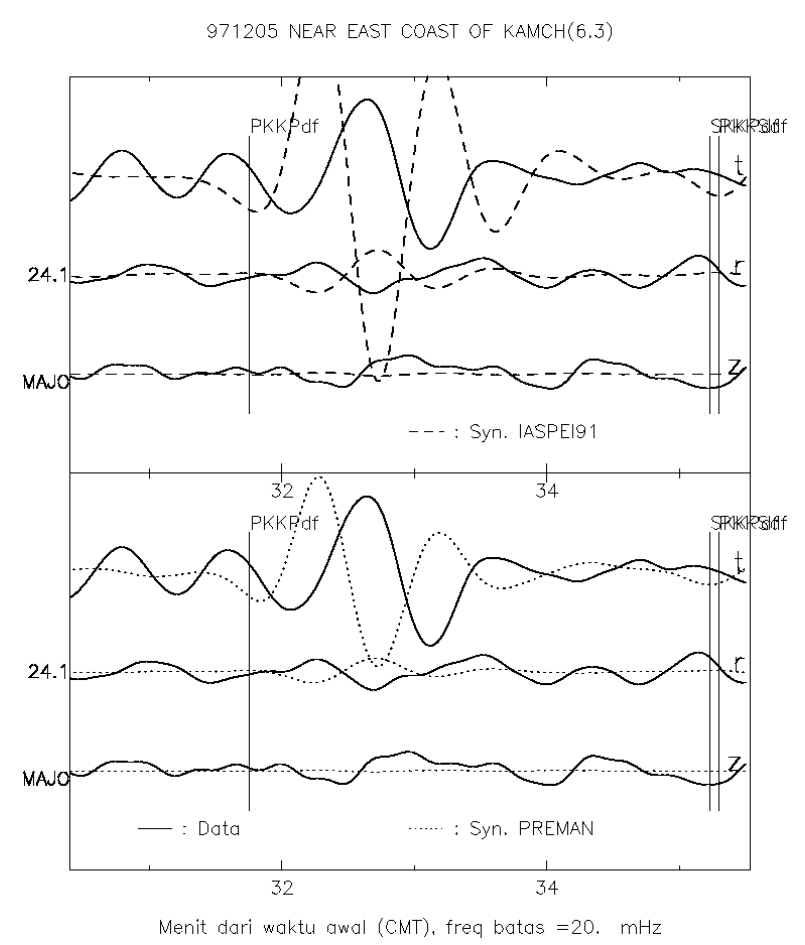

Gambar 6: Perbandingan seismogram pada jendela waktu gelombang $\mathrm{ScS}-\mathrm{ScS}$ pada stasiun MAJO. 
dikasi, bagaimana seharusnya model lapisan di mantel bawah. Pengamatan struktur mantel bawah dengan waveform ini lebih baik daripada pengamatan dengan catatan waktu tempuh gelombang SKKS-S [13], dimana untuk pencatatan waktu tempuh fase gelombang tersebut diperlukan stasiun-stasiun observasi yang jarak epientralnya di atas $83^{\circ}$.

\section{SIMPULAN}

Kedua model bumi mempunyai perbedaan ketebalan kulit bumi sebesar $15 \mathrm{~km}$. Nilai ini lebih kecil dibandingkan dengan panjang gelombang sekitar $240 \mathrm{~km}$ yang digunakan dalam analisis penelitian ini. Walaupun demikian pengaruh perbedaan ketebalan kulit bumi terhadap amplitudo dan waktu tiba gelombang bersifat sangat peka. Lintasan fase gelombang $\mathrm{ScS}$ dan $\mathrm{ScS}-\mathrm{ScS}$ dalam kulit bumi memiliki porsi yang kecil dibandingkan keseluruhan lintasan gelombang dalam medium bumi. Walaupun porsi kecil, tampak bahwa pengaruh kulit bumi terhadap fase-fase gelombang ini cukup signifikan. Masalah yang dijumpai dalam penelitian ini ini belum banyak dieksplorasi oleh para seismologi lainnya. Kesimpulan dari penelitian ini adalah, struktur inti bumi (CMB) belum diketahui strukturnya lebih detil, jika pengaruh dari ketebalan kulit bumi tampak sangat nyata.

\section{Ucapan Terima Kasih}

Penulis mengucapkan terima kasih pada Lembaga Seismologi IRIS [12] yang telah menyediakan data digital dari rekaman seismogram dan file-file unit response. Tak lupa kerjasama dengan Institut Geophysics der Uni Stuttgart, dimana kami telah bersama mengembangkan program GEMINI.
[1] Gubbins, D., Seismology and Plate Tectonics (Cambridge University Press, Cambridge, 1990).

[2] Aki, K. and Richards, P., Quantitative Seismology, Theory and Methods, Band 1 (Freeman, San Fransisco, 1980).

[3] Dreger, D.S., Time-Domain Moment Tensor INVerse Code (TDMT INVC)(The Berkeley Seismological Laboratory (BSL), report number 8511, 2002).

[4] Bagus J.S., Möglichkeiten und Grenzen der Modellierung vollständiger langperiodischer Seismogramme, Doktorarbeit, Berichte Nr. 12, Inst. für Geophysik, Uni. Stuttgart, 1999.

[5] Dalkolmo, J., Synthetische Seismogramme für eine sphärisch symmetrische, nichtrotierende Erde durch direkte Berechnung der Greenschen Funktion, Diplomarbeit, Inst. für Geophys., Uni. Stuttgart, 1993.

[6] Friederich, W. and Dalkolmo, J., Geophys. J. Int., 122, 537-550 (1995).

[7] Kennett, B.L.N., IASPEI 1991, Seismological Tables, Research
School of Earths Sciences (Australian National University, 1991).

[8] Dziewonski, A.M. and Anderson, D.L., Phys. of the Earth and Plan. Int., 25, 297-356 (1981).

[9] Kennett ,B.L.N. and Gorbatov1, A., Phys. of the Earth and Plan. Int., 146, 87 - 100 (2004).

[10] Zhao, D, Phys. of the Earth and Plan. Int., 146, 3 - 34 (2004).

[11] Dziewonski, A.M., Chou, T.A. and Woodhouse, J.H., Jour. of Geophys. Res., 86, 2825-2852 (1981).

[12] IRIS, Incorporated Research Institutions for Seismology, Data Bank Center, dmc.iris.washington.edu.

[13] Wysession, M.E., Valenzuela, R.W., Zhu, A. and Bartk, L., Phys. of the Earth and Plan. Int., 92, Issue 1-2, 67 - 84 (1995).

[14] Bagus J.S., Pengaruh ketebalan kulit bumi pada tinggi amplitudo gelombang P, Majalah IPTEK 2004, Vol 15, No. 3, 1 - 6 (2004). 